\title{
The Effect of Solution-focused Brief Group Counseling upon the Perceived Social Competences of Teenagers
}

\author{
Bünyamin Ateş \\ Correspondence: Bünyamin Ateş, PhD, Faculty of Education, Erzincan University, Erzincan, 24000, Turkey
}

Received: March 10, 2016

Accepted: March 31, $2016 \quad$ Online Published: April 1, 2016

doi:10.11114/jets.v4i7.1443

URL: http://dx.doi.org/10.11114/jets.v4i7.1443

\begin{abstract}
In this study, the effect of solution-focused brief group counseling upon the perceived social competences of teenagers was investigated. The study group included 24 volunteer students who took lower scores rather than the ones obtained from perceived social competence scale pre-test measurements out of 227 students studying at a high school in Provincial center of Erzincan in 2015-2016 academic year. The research was an experimental study based upon experimental-control-placebo group pre-test, post-test and follow-up measurement design. Perceived Social Competence Scale and Personal Information Form were used as data collection tools. For the analysis of the obtained data, Kruskal Wallis H Test for Independent Samples, Mann Whitney U Test for Independent Samples and Wilcoxon Signed Rank Test for Paired Samples as non-parametric analyses were used. As result of the study's post-test measurements, it was determined that there was a significant increase at perceived social competence levels of the teenagers in experimental group rather than the control and placebo groups. The increase perceived social competences of the teenagers in the experimental group was noticed to be maintained in follow-up measurements carried out 3 months later the post-test measurements. In control and placebo groups, no significant difference was found between pre-test, post-test and follow-up test scores. As result of this study, solution-focused brief group counseling was determined to be efficient in increasing the perceived social competence levels of teenagers.
\end{abstract}

Keywords: solution-focused brief group counseling, teenager, group psychological counseling, perceived social competence

\section{Introduction}

There are several factors affecting the individuals born into a world with a social structure to maintain their existence successfully, harmoniously and efficiently. One of these factors include social competence perception of individuals shaped by a social structure being lived in as starting in the first years of life. Social competence has tried to been conceptually defined by several researchers. Gresham, Sugai \& Horner (2001) defined social competence as individuals' judgments and evaluations about their performance related to a specific social task. According to Ferris, Perrewé \& Douglas (2002), social competence is individuals' efficiency in their social relationships. In another definition, social competence was defined as coping with difficulties encountered in specific social situations, actualizing/achieving specific social targets in a social context using the proper methods as result of a positive development (Ford, 1982). Social competence is the belief of individuals towards establishing a social relationship (Bilgin, 1999).

It was possible to notice in addition to these definitions that the concept of social competence and the concept of social skill have sometimes been used as synonyms, and no specific distinction has been made between the concepts. However, some researchers suggested that these two concepts are different from each other. According to these researchers, social skill is the ability of individuals for starting, maintaining and ending a specific social task. And social competence is the result of assessing individuals' performance at a social task. These assessments are carried out according to the judgments of people such as families, teachers and peers, to the results obtained from a standard measurement tool, to specific criteria, to individuals' acceptance by their friends, to popularity among the friends and maintaining their friendly relationships (Bacanl1, 2012; Gresham, Sugai \& Horner, 2001). In this sense, social competence is an organized structure developing upon the reactions of social surrounding and past experiences and including the viewpoints of both the self and others (Coleman, 2003; Rose-Krasnor, 1997). The standards of this organized structure includes task, assessment, criteria, age, gender, role, statue, and culture, etc. (Ford, 1982; Torres, Cardelle-Elawar, Mena \& Sanchez, 2003; Rose-Krasnor, 1997). 
The researchers who have studies upon the concept of social competence mentioned that social competence included dimensions as knowledge, skill, attitude (Ten Dam \& Volman, 2007), social enterprise, social mutuality, and social self-control (Usher, Burrows, Schwartz \& Henderson, 2015), cooperation and communication, empathy, self-awareness, self-competence (Simões, Matos \& Social, 2012), social, cognitive, affective and personal dimensions (Ford,1982; Lianos, 2015; Márquez, Martín \& Brackett, 2006; Ferris, Perrewé \& Douglas, 2002). Social competence is a significantly important skill for individuals' being independent, coping with difficulties, maintaining their social relationships efficiently and in a qualified way, and participating into social and group activities actively, etc. (Gedviliene, 2014). Social competence provides individuals to feel themselves more secure in interpersonal interactions, to be more productive and so to perceive themselves more competent in interpersonal relationships (Erözkan, 2013).

When the developmental areas of individuals are considered as a whole, the change in one developmental area of an individual is possible to affect the other areas. In this sense, social competence has turned into a factor affecting the development areas of individuals, social competence as the leading. Social competence is a structure affecting the mental health of individuals as well as affecting their social life. It is possible to notice this in studies carried out upon social competence. In the studies carried out upon social competence, positive relationships were determined between assertiveness (Castedo, Juste \& Alonso, 2015), qualified friendship relationships (Boling, Barry, Kotchick \& Lowry, 2011), social support (Elias \& Haynes, 2008), self-respect, social adaptation (Connolly, 1989), subjective well-being (Simões, Matos \& Social, 2012), personal traits such as conscientiousness, openness, and extraversion (Lianos, 2015), and academic success (Malik \& Shujja, 2013). In contrast to these, negative relationships were determined between social competence and behavioral problems (Yalçın, 2009), solitude (Zhang et al., 2014), social anxiety (Usher, Burrows, Schwartz \& Henderson, 2015), shyness (Chen et al., 2014) and depression (Payne \& Jahoda, 2004).

When the literature related to the same subject was reviewed, it could be noticed that the studies carried out upon social competence were generally on a descriptive style; namely, the variables that were possible to affect social competence or in a correlation with social competence were emphasized. Such studies were significant in terms of the literature; however, experimental studies based upon psychologic counseling theory were noticed to be not studied adequately. In this sense, it has been considered that experimental studies related to increasing the social competence perceptions of individuals will provide significant contributions upon the literature. In accordance with this, it was considered that investigating the effect of solution-focused brief group counseling as one of the most current approaches upon the social competence perception would be beneficial in terms of the literature.

Solution-focused brief psychologic counseling is one of the last few current psychological counseling approaches developed by Brief Therapy in the USA. Steve de Shazer, Insoo Kim Berg, Bill O'Hanlon, Michelle Weiner-Davis, and Scott Miller can be listed among the representatives of this approach. This approach regards the counselee and change in an optimist way. It emphasizes the achievements, strengths, resources, changes, exceptional moments, beneficial acts, and solutions of individuals. In this approach, background and origin of the problem is not investigated. Instead of this, present, future and solutions are regarded. In this approach, as well, the number of sessions does not exceed 10, and it generally varies between 4 and 6 sessions. Main techniques of the approach include pre-session change technique, formulization of first session task, miracle question, scaling questions, exception situations, coping questions and crystal ball technique (Ateş, 2015; De Shazer, 1985; De Shazer and Berg, 1997; De Jong and Berg, 1998; Murphy, 1997; Lethem, 2002; Murdock, 2012; Sklare, 2013).

Within the context of this information, it was considered that social competence was significantly important in any stages of life, it became more remarkable in adolescence period as a period when the effect of social surrounding was regarded more, feedbacks of social surrounding and the social competence perception shaped in this respect were the leading factor affecting the social relationships, and metal health of teenagers. When considering that social competence perceived at a low level negatively affected social efficiency of teenagers in their social communication and interactions, the studies carried out upon increasing the social competence perceptions of teenagers were beneficial and significant in terms of their mental health. In this sense, the purpose of the study was expressed as investigating the effect of solution-focused brief group counseling upon the perceived social competences of teenagers. In this study carried out in accordance with this purpose, answer was sought to the question of "Is solution-focused brief group counseling efficient upon the perceived social competences of teenagers?"

\section{Method}

\subsection{Research Model}

The research was an experimental study based upon experimental-control-placebo group pre-test, post-test and follow-up measurement design. The experimental design related to the study was presented in Table 1. 
Table 1. Experimental Design of the Study

\begin{tabular}{|c|c|c|c|c|}
\hline Group & $\mathbf{N}$ & Pre-test & Implementation & Post-test/Follow-up \\
\hline $\begin{array}{l}\text { Experimental } \\
\text { G. }\end{array}$ & 8 & $\begin{array}{l}\text { Perceived } \\
\text { Social } \\
\text { Competence } \\
\text { Scale }\end{array}$ & 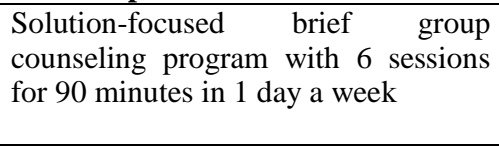 & $\begin{array}{l}\text { Perceived Social } \\
\text { Competence Scale }\end{array}$ \\
\hline Control G. & 8 & $\begin{array}{l}\text { Perceived } \\
\text { Social } \\
\text { Competence } \\
\text { Scale }\end{array}$ & No implementation was carried out & $\begin{array}{l}\text { Perceived Social } \\
\text { Competence Scale }\end{array}$ \\
\hline Placebo G. & 8 & $\begin{array}{l}\text { Perceived } \\
\text { Social } \\
\text { Competence } \\
\text { Scale }\end{array}$ & $\begin{array}{l}\text { Program without therapeutic effect as } \\
\text { different from experimental process } \\
6 \text {-session for } 90 \text { minutes in } 1 \text { day a } \\
\text { week }\end{array}$ & $\begin{array}{l}\text { Perceived Social } \\
\text { Competence Scale }\end{array}$ \\
\hline
\end{tabular}

\subsection{Study Group}

The study group included 24 volunteer students who took lower scores rather than the ones obtained from perceived social competence scale pre-test measurements out of 227 students studying at a high school in Provincial center of Erzincan in 2015-2016 academic year. The study groups included 8 students each with 4 females and 4 males. The age interval of the students varied between 14 and 18 .

\subsection{Data Collection Tools}

\subsubsection{Perceived Social Competence Scale}

The scale was developed by Anderson-Butcher, Iachini \& Amorose (2007), and adapted into Turkish culture by Sarıçam, Akın, Akın, \& Çardak, (2013). The results obtained from the confirmatory factor analyses proved that 6 items were as one factor in the original form, and the one-dimensional model was well-fit $\left(x^{2}=7.34, \mathrm{df}=7, \mathrm{RMSEA}=.010, \mathrm{CFI}=1.00\right.$, $\mathrm{RFI}=0.99, \mathrm{IFI}=1.00, \mathrm{AGFI}=.98, \mathrm{GFI}=.99, \mathrm{NFI}=.99$ and $\mathrm{SRMR}=.018$ ). Factor loadings varied between .57 and .80 . In terms of the internal consistency, Cronbach alpha coefficient of the scale was found .80. Corrected item-total correlations varied between .52 and .66. Within the scope of this study, Cronbach Alpha reliability coefficient was determined to be .82 for whole scale.

\subsubsection{Personal Information Form}

Within the scope of the research, personal information form was developed to obtain personal information related to the students, and the study group was created by the researcher.

\subsection{Data Analysis}

In terms of the primary analysis of the data obtained in this study, whether the data had a parametric value or not was investigated with scatter plots and Shapiro-Wilks normality test; and the groups were determined to be scattered normally. In this sense, Kruskal Wallis H Test for Independent Samples, Mann Whitney U Test for Independent Samples and Wilcoxon Signed Rank Test for Paired Samples as non-parametric analyses were used for the analysis of the obtained data. Data analyses were performed in computer environment via SPSS software package. In the study, .05 level of significance was accepted (Büyüköztürk, 2011; Seçer, 2015).

\subsection{Process}

In order to create the study group, appropriate course hours of the students were determined, the students were informed about the study in these course hours, and Perceived Social Competence Scale was performed to 227 students who wanted to participate into the study as pre-test. Subsequently, scale scores of the students ranked from low to high, and 24 students who wanted to participate into the study voluntarily as result of the pre-interviews with low social competence score were determined. This determined 24 students were distributed randomly into experimental, control and placebo groups including 8 participants in each group. Six-session solution-focused brief group counseling based upon solution-focused brief psychological counseling philosophy, principles and techniques was performed to the students in the experimental group. A 6-session program (environmental problems and environmental consciousness training program) without a therapeutic effect as different from the program performed to the experimental group was administered to the students in the placebo group. The sessions were held for nearly 90 minutes once a week. The students in the control group were provided to maintain their normal educational activities without carrying out any processes. After completing planned group session processes, post-test (Perceived Social Competence Scale) was performed to all three groups. Three months later the post-test measurements, follow-up measurements were carried out in order to determine the permanence of the experimental process. At the end of the study, a 75 -minute seminar was held to the students in the control and placebo groups in order to adhere to the occupational ethics. 


\subsection{Development of the Program and Implementation Process}

In order to develop this program prepared for increasing the perceived social competence levels of teenagers, descriptive and experimental studies carried out in Turkey and abroad upon solution-focused brief group counseling and social competence were primarily reviewed. The framework of the program developed within the scope of this study was regarded to be in accordance with basic philosophy, principles and techniques of solution-focused brief psychological counseling.

After creating the framework of the program, a four-session study was carried out with 8 students within the scope of program's pre-implementation in the high school where the study would be conducted. Deficiencies of the program were determined in this four-session pre-implementation study, and the program was provided to be more appropriate for the study group. Implementation process of the program was carried out as such in short: $1^{\text {st }}$ Session (Pre-session change and formulization of the first session task): In the first session, students got acquainted with each other, positive targets and rules were created. General information on solution-focused brief psychological counseling and social competence was shared. In this session, the techniques of pre-session change and formulization of the first-session task were used. $2^{\text {nd }}$ Session (Solutions): In this session, the positive changes and solutions group members observed or experienced in their life in terms of their social competence perceptions were focused. In this session, miracle question technique was used. $3^{\text {rd }}$ Session (Resources and coping): In this session, achievements, solutions and strength of group members that would provide contributions upon increasing their social competence perceptions were focused. During this session, the technique of coping questions was used. $4^{\text {th }}$ Session (Exceptions): In this session, what group members did, how the situation was, what they felt, what were different, and what was possible to maintain these moments when they perceived themselves at a high level in terms of their social competence were focused. For this, the technique of exceptional moments was used. $5^{\text {th }}$ Session (Crystal Ball): In this session, the group members were asked to design their own situations in a future time when they would have high level of social competence perceptions, and these situations were shared. $6^{\text {th }}$ Session (Finalization): In this session, evaluations of the group members were taken, and the group process was finalized. During this group process, "scaling questions" was used for group members' evaluating their own, and the counseling process.

\section{Findings}

In this study, perceived social competence pre-test scores of the groups were analyzed using Kruskal Wallis H Test for Independent Samples in order to determine whether the pre-implementation groups were equal to each other or not, and no significant difference was found between perceived social competence pre-test scores of the groups $\left(\chi^{2}(\mathrm{df}=2, \mathrm{n}=24)\right.$ $=.435, \mathrm{p}>.05)$. This finding proved that perceived social competence pre-test scores of the pre-implementation groups were equal to each other. Kruskal Wallis H Test for Independent Samples analysis results related to the perceived social competence pre-test scores of the groups were presented in Table 2.

Table 2. Kruskal Wallis H-Test for Independent Samples Analysis Results Related to the Pre-test Scores of the Groups

\begin{tabular}{llllrc}
\hline Group & $\mathrm{N}$ & Mean Rank & $\mathrm{df}$ & $\chi^{2}$ & $\mathrm{p}$ \\
\hline Experimental & 8 & 11.31 & 2 & .435 & .805 \\
Control & 8 & 12.63 & & & \\
Placebo & 8 & 13.56 & & & \\
\hline
\end{tabular}

After determining the equality of groups' pre-test scores, perceived social competence post-test scores of the groups were analyzed using Kruskal Wallis H Test for Independent Samples in order to determine whether there was a significant difference between perceived social competence post-test scores of the groups, and obtained results were presented in Table 3.

Table 3. Kruskal Wallis H-Test for Independent Samples Analysis Results Related to the Post-test Scores of the Groups

\begin{tabular}{lrlllll}
\hline Group & $\mathrm{N}$ & Mean Rank & $\mathrm{df}$ & $\chi^{2}$ & $\mathrm{p}$ & $\begin{array}{l}\text { Significant } \\
\text { difference }\end{array}$ \\
\hline Experimental & 8 & 20.50 & 2 & 15.63 & .000 & A-B, A-C \\
Control & 8 & 8.94 & & & \\
Placebo & 8 & 8.06 & & & & \\
\hline $\boldsymbol{A}=$ Experimental Group & $\boldsymbol{B}=$ Control Group & $\boldsymbol{C}=$ Placebo Group & &
\end{tabular}

When Table 3 was analyzed, significant difference was noticed between perceived social competence post-test scores of the groups $\left(\chi^{2}(\mathrm{df}=2, \mathrm{n}=24)=15.63, \mathrm{p}<.05\right)$. Mann Whitney U-Test was performed in order to determine the source of the difference among the groups. According to these test results, perceived social competence levels of the students in the experimental group were found to be higher rather than the levels of the control and placebo groups, and the difference was significant. In addition to this analysis, Wilcoxon Signed Rank Test for Paired Samples was performed in order to determine whether there was a significant difference between pre-test scores and post-test scores of the groups, 
and the results were presented in Table 4.

Table 4. Wilcoxon Signed Rank Test for Paired Samples Analysis Results Related to Pre-Test and Post-Test Scores of the Groups

\begin{tabular}{lllcccc}
\hline $\begin{array}{l}\text { Post-test } \\
\text { Pre-test }\end{array}$ & - & $\mathbf{N}$ & $\begin{array}{l}\text { Mean } \\
\text { Rank }\end{array}$ & $\begin{array}{l}\text { Sum of } \\
\text { Ranks }\end{array}$ & z & p \\
\hline $\begin{array}{l}\text { Experimental } \\
\text { Group }\end{array}$ & $\begin{array}{l}\text { Negative } \\
\text { Ranks } \\
\text { Positive } \\
\text { Ranks } \\
\text { Ties }\end{array}$ & 0 & .00 & .00 & -2.54 & .011 \\
& $\begin{array}{l}\text { Negative } \\
\text { Ranks } \\
\text { Control }\end{array}$ & 2 & 4.50 & 36.00 & & \\
Group & $\begin{array}{l}\text { Positive } \\
\text { Ranks } \\
\text { Ties }\end{array}$ & 5 & 5.25 & 10.50 & -.632 & .527 \\
& $\begin{array}{l}\text { Negative } \\
\text { Ranks } \\
\text { Positive }\end{array}$ & 4 & 3.50 & 17.50 & & \\
\hline $\begin{array}{l}\text { Panks } \\
\text { Group }\end{array}$ & 3 & 4.38 & 17.50 & -.604 & .546 \\
& Ties & 1 & 3.50 & 10.50 & & \\
\hline
\end{tabular}

As result of the Wilcoxon Signed Rank Test for Paired Samples performed to determine whether there was a significant difference between pre-test scores and post-test scores of the groups, no significant difference was found between pre-test scores and post-test scores of the control group $(\mathrm{z}=-.632, \mathrm{p}>.05)$ and placebo group $(\mathrm{z}=-.604, \mathrm{p}>.05)$. However, a significant difference was determined between pre-test scores and post-test scores of the experimental group $(z=-2.54$, $\mathrm{p}<.05)$. When mean rank and sum of the difference scores were considered, this difference was noticed to be in favor of positive ranks and post-test score. This difference occurred in favor of the experimental group follow-up measurement was carried out 3 months later the post-test measurements in order to specify the permanence of this difference in favor of the experimental group. The data obtained from the follow-up test were analyzed using Kruskal Wallis $\mathrm{H}$ Test for Independent Samples, and the results were presented in Table 5.

Table 5. Kruskal Wallis H Test for Independent Samples Analysis Results Related to Follow-up Test Scores of the Groups

\begin{tabular}{lrlllll}
\hline Group & $\mathrm{N}$ & Mean Rank & $\mathrm{df}$ & $\chi^{2}$ & $\mathrm{p}$ & $\begin{array}{l}\text { Significant } \\
\text { Difference }\end{array}$ \\
\hline Experimental & 8 & 20.50 & 2 & 15.74 & .000 & A-B, A-C \\
Control & 8 & 9.13 & & & \\
Placebo & 8 & 7.88 & & & \\
\hline $\boldsymbol{A}=$ Experimental Group & $\boldsymbol{B}=$ Control Group & $\boldsymbol{C}=$ Placebo Group & &
\end{tabular}

When Table 5 was analyzed, a significant difference was noticed between perceived social competence follow-up test scores of the groups $\left(\chi^{2}(\mathrm{df}=2, \mathrm{n}=24)=15.74, \mathrm{p}<.05\right)$. Mann Whitney U-Test was performed to determine the source of the difference between the groups. According to the results of this test, perceived social competence levels of the students in the experimental group were noticed to be higher rather than the scores of the students in control and placebo groups, and the difference was significant. These findings proved that the difference occurred in favor of the experimental group in post-test scores of the groups was also present in follow-up test. In addition to this analysis, Wilcoxon Signed Rank Test for Paired Samples was performed in order to determine whether there was a significant difference between post-test scores and follow-up scores of the groups, and the results were presented in Table 6. 
Table 6. Wilcoxon Signed Rank Test for Paired Samples Results Related to the Post-Test and Follow-up Test Scores of the Groups

\begin{tabular}{|c|c|c|c|c|c|c|}
\hline $\begin{array}{l}\text { Follow-up } \\
\text { Test/ Posttest }\end{array}$ & & $\mathbf{N}$ & $\begin{array}{l}\text { Mean } \\
\text { Rank }\end{array}$ & $\begin{array}{l}\text { Sum of } \\
\text { Ranks }\end{array}$ & $\mathbf{z}$ & $\mathbf{p}$ \\
\hline \multirow{4}{*}{$\begin{array}{l}\text { Experimental } \\
\text { Group }\end{array}$} & $\begin{array}{l}\text { Negative } \\
\text { Ranks }\end{array}$ & 4 & 3.38 & 13.50 & -.641 & .521 \\
\hline & Positive & 4 & 5.63 & 22.50 & & \\
\hline & Ranks & & & & & \\
\hline & Ties & 0 & & & & \\
\hline \multirow{4}{*}{$\begin{array}{l}\text { Control } \\
\text { Group }\end{array}$} & Negative & 3 & 5.83 & 17.50 & -.072 & .943 \\
\hline & Ranks & & & & & \\
\hline & Positive & 5 & 3.70 & 18.50 & & \\
\hline & Ranks & & & & & \\
\hline \multirow{4}{*}{$\begin{array}{l}\text { Placebo } \\
\text { Group }\end{array}$} & $\begin{array}{l}\text { Tres } \\
\text { Negative }\end{array}$ & 3 & 6.67 & 20.00 & -285 & 776 \\
\hline & Ranks & & & & & \\
\hline & Positive & 5 & 3.20 & 16.00 & & \\
\hline & Ranks & & & & & \\
\hline
\end{tabular}

As result of the Wilcoxon Signed Rank Test for Paired Samples performed to determine whether there was a significant difference between post-test scores and follow-up test scores of the groups, no significant difference was found between post-test scores and follow-up test scores of the experimental group $(\mathrm{z}=-.641, \mathrm{p}>.05)$, control group $(\mathrm{z}=-.072, \mathrm{p}>.05)$, and placebo group $(\mathrm{z}=-.285, \mathrm{p}>.05)$. According to these findings, the increase at perceived social competence levels of the teenagers in the experimental groups was also possible to be mentioned as being present in the follow-up test.

\section{Conclusion, Discussion and Recommendations}

As result of the post-test measurements of the study carried out to determine the effect of solution-focused brief group counseling upon the perceived social competences of teenagers, pre-test measurements in perceived social competence levels of the teenagers in the experimental group increased more than the perceived social competence levels of the teenagers in control and placebo groups. The increase at perceived social competence levels of the teenagers in the experimental group was noticed to be maintained in the follow-up measurements performed 3 months later the post-test measurements. In control and placebo groups, no significant difference was found between pre-test, post-test and follow-up test scores. As result of this study, solution-focused brief counseling was noticed to be efficient upon increasing the perceived social competence levels of the teenagers in the experimental group. This change that was noticed in the experimental group was supported through the oral feedbacks received from the students. At the end of this study, it was possible to mention that solution-focused brief group counseling was efficient upon the perceived social competence of the teenagers, and this effect was protected, as well, in follow-up test.

In the literature review upon the social competence, it was noticed that the relationship of social competence was generally focused on different variables. Some of these variables included personality traits, communication skills, interpersonal problem solving skills, friendly relationships, behavioral problems, social anxiety, gender, and solitude (Boling, Barry, Kotchick, \& Lowry, 2011; Erözkan, 2013; Lianos, 2015; Torres, Cardelle- Elawar, Mena, \& Sanchez, 2003; Usher, Burrows, Schwartz \& Henderson, 2015; Yalçın, 2009; Zhang et al., 2014). In terms of the literature, determination of the variables possible to be correlated with social competence was important, and the studies carried out upon determining the variables for increasing the perceived social competence of individuals were considered to be important. In the literature review upon this, no study was noticed upon increasing the perceived social competence levels of the individuals in Turkey. In abroad, however, different studies were found upon perceived social competence levels of the individuals (Beelmann, Pfingsten \& Lösel, 1994; Glass, Guli \& Semrud-Clikeman, 2000; Gooding, 2011; Hennessey, 2007; Holsen, Smith \& Frey, 2008; Langeveld, Gundersen \& Svartdal, 2012; Nielsen, Meilstrup, Nelausen, Koushede \& Holstein, 2015; Schonert- Reichl \& Lawlor, 2010). However, these studies were noticed not to be depended upon a specific psychological counseling theory, in general. In this sense, this study in which the effect of solution-focused brief counseling as a modern psychological counseling approach upon the perceived social competence levels of the teenagers was investigated was considered to provide significant contributions upon the literature.

Establishing and maintaining efficient, healthy, and appropriate relationships with the people around at any period of life is essential for the social and personal development of individuals as a social being, and this importance has been more remarkable during the adolescence period. Because teenagers regard the relationships established with the social surrounding more than the ones with their families and being accepted by their social surrounding. Teenagers' establishing and maintaining efficient and appropriate social relationships, expressing their requests and needs properly, 
and creating efficient solutions for the problems they encounter are considered to be in a relation with their social competence perception level. Social competence level perceived by the teenagers can not only affect their social relationships but also their mental health. The teenagers with low level of perceived social competence can avoid from social relationships, in general, and cannot have adequate efficiency and competence necessary for these relationships. Low level of perceived social competence level can also negatively affect other areas of teenagers such as academic success and personal development. The teenagers with low level of perceived social competence can experience various social, psychological and academic problems in this period, and can also have problems in different areas of life such as the occupational areas in post-adolescence periods. Because these individuals can experience loss of function in social and other areas due to their low level of belief and perceptions upon their competences and efficiencies in their social relationships. It should be kept in mind that developmental areas of individuals are in relationship with each other as a whole; namely, a problem that occurs in one area certainly affects the others. These recommendations were offered as result of this study:

- This study was carried out with teenagers in the educational process. A similar study can also be carried out with teenagers who have not studied.

- The study group of this research included teenagers. Such a study can also be carried out with individuals in different developmental periods.

- The content of the program developed within the scope of the research can be changed according to different needs.

- Considering the protective function adapted in understanding of modern guidance, studies such as seminars, and educational groups, etc. can be conducted for increasing the awareness levels of all students upon social competence in order to raise individuals with high level of social competence.

\section{References}

Ateş, B. (2015). Çözüm odaklı kısa süreli psikolojik danışma, kuram ve uygulama. Ankara: Vize Yayıncıllk.

Bacanlı, H. (2012). Sosyal beceri eğitimi. (4. Baskı). Ankara: Pegem Akademi Yayıncılık.

Beelmann, A., Pfingsten, U., \& Lösel, F. (1994). Effects of training social competence in children: A meta-analysis of recent evaluation studies. Journal of clinical child psychology, 23(3), 260-271. http://dx.doi.org/10.1207/s15374424jccp2303_4

Bilgin, M. (1999). 14-18 yaş grubu ergenlere yönelik sosyal yetkinlik beklentisi ölçeği geliştirme çalışması. Türk Psikolojik Danlşma ve Rehberlik Dergisi, 2(12), 7-15.

Boling, M. W., Barry, C. M., Kotchick, B. A., \& Lowry, J. (2011). Relations among early adolescents' parent-adolescent attachment, perceived social competence, and friendship quality. Psychological Reports, 109(6), 819-841. http://dx.doi.org/10.2466/02.07.09.21.PR0.109.6.819-841

Büyüköztürk, Ş. (2011). Sosyal bilimler için veri analizi el kitabı. (15. Baskı). Ankara: Pegem Akademi Yayıncılık.

Castedo, A. L., Juste, M. P., \& Alonso, J. D. (2015). Social competence: Evaluation of assertiveness in Spanısh adolescents. Psychological Reports, 116(1), 219-229. http://dx.doi.org/10.2466/21.PR0.116k12w5

Chen, X., Zhang, G., Liang, Z., Zhao, S., Way, N., Yoshikawa, H., \& Deng, H. (2014). Relations of behavioural inhibition with shyness and social competence in Chinese children: Moderating effects of maternal parenting. Infant and Child Development, 23(3), 343-352. http://dx.doi.org/10.1002/icd.1852

Coleman, P. K. (2003). Perceptions of parent-child attachment, social self-efficacy, and peer relationships in middle childhood. Infant and Child Development, 12, 351-368. http://dx.doi.org/10.1002/icd.316

Connolly, J. (1989). Social self-efficacy in adolescence: Relations with self-concept, social adjustment, and mental health. Canadian Journal of Behavioural Science, 21(3), 258-269. http://dx.doi.org/10.1037/h0079809

De Jong, P., \& Berg, I. K. (1998). Interviewing for solutions. Pacific Grove CA: Brooks/ Cole.

De Shazer, S. (1985). Keys to solution in brief therapy. New York: W.W. Norton\& Company Inc.

De Shazer, S., \& Berg I. K. (1997). 'What works?' Remarks on research aspects of solution-focused brief therapy. Journal of Family Therapy, 19, 121-124. http://dx.doi.org/10.1111/1467-6427.00043

Elias, M. J., \& Haynes, N. M. (2008). Social competence, social support, and academic achievement in minority, low-income, urban elementary school children. School Psychology Quarterly, 23(4), 474-495. http://dx.doi.org/10.1037/1045-3830.23.4.474

Erözkan, A. (2013). İletişim becerileri ve kişilerarası problem çözme becerilerinin sosyal yetkinliğe etkisi. Kuram ve 
Uygulamada Ĕgitim Bilimleri, 13(2), 731-745.

Ferris, G. R., Perrewé, P. L., \& Douglas, C. (2002). Social effectiveness in organizations: Construct validity and research directions. Journal of Leadership \& Organizational Studies, 9(1), 49-63. http://dx.doi.org/10.1177/107179190200900104

Ford, M. E. (1982). Social Cognition and Social Competence in Adolescence. Developmental Psychology, 18(3), 323-340. http://dx.doi.org/10.1037/0012-1649.18.3.323

Gedviliene, G. (2014). The case of Lithuania and Belgium: Teachers and students' social competence. European Scientific Journal, 10(13), 181-294.

Glass, K. L., Guli, L. A., \& Semrud-Clikeman, M. (2000). Social competence intervention program: A pilot program for the development of social competence. Journal of Psychotherapy in Independent Practice, 1(4), 21-33. http://dx.doi.org/10.1300/J288v01n04_03

Gooding, L. F. (2011). The effect of a music therapy social skills training program on improving social competence in children and adolescents with social skills deficits. Journal of Music Therapy, 48(4), 440-462. http://dx.doi.org/10.1093/jmt/48.4.440

Gresham, F. M., Sugai, G., \& Horner, R. H. (2001). Interpreting outcomes of social skills training for students with high-incidence disabilities. Exceptional children, 67(3), 331-344.

Hennessey, B. A. (2007). Promoting social competence in school-aged children: The effects of the open circle program. Journal of School Psychology, 45(3), 349-360. http://dx.doi.org/10.1016/j.jsp.2006.11.007

Holsen, I., Smith, B. H., \& Frey, K. S. (2008). Outcomes of the social competence program second step in Norwegian elementary schools. School Psychology International, 29(1), 71-88. http://dx.doi.org/10.1177/0143034307088504

Langeveld, J. H., Gundersen, K. K., \& Svartdal, F. (2012). Social competence as a mediating factor in reduction of behavioral problems. Scandinavian Journal of Educational Research, 56(4), 381-399. http://dx.doi.org/10.1080/00313831.2011.594614

Lethem, J. (2002). Brief solution focused therapy. Child and Adolescent Mental Health, 7(4), 189-192. http://dx.doi.org/10.1111/1475-3588.00033

Lianos, P. G. (2015). Parenting and social competence in school: the role of preadolescents' personality traits. Journal of Adolescence, 41, 109-120. http://dx.doi.org/10.1016/j.adolescence.2015.03.006

Malik, F., \& Shujja, S. (2013). Social competence and school systems as predictor of academic achievement in high and low achieving Pakistani school children. Journal of Behavioral Sciences, 23(1), 77-92.

Márquez, P. G. O., Martín, R. P., \& Brackett, M. A. (2006). Relating emotional intelligence to social competence and academic achievement in high school students. Psicothema, 18,118-123.

Murdock, N. L. (2012). Psikolojik danışma ve psikoterapi kuramları. (Çev. F. Akkoyun). Ankara: Nobel Akademik Yayıncilik.

Murphy, J. J. (1997). Solution-focused counseling in middle and high schools. Alexandria, VA: American Counseling Association.

Nielsen, L., Meilstrup, C., Nelausen, M. K., Koushede, V., \& Holstein, B. E. (2015). Promotion of social and emotional competence: Experiences from a mental health intervention applying a whole school approach. Health Education, 115(3/4), 339-356. http://dx.doi.org/10.1108/HE-03-2014-0039

Payne, R., \& Jahoda, A. (2004). The Glasgow Social Self - Efficacy Scale - a new scale for measuring social self efficacy in people with intellectual disability. Clinical Psychology \& Psychotherapy, 11(4), 265-274. http://dx.doi.org/10.1002/cpp.412

Rose-Krasnor, L. (1997). The nature of social competence: A theoretical review. Social development, 6(1), 111-135. http://dx.doi.org/10.1111/j.1467-9507.1997.tb00097.x

Sarıçam, H., Akın, A., Akın, Ü., \& Çardak, M. (2013). Algılanan sosyal yetkinlik ölçeğinin Türkçeye uyarlanması: geçerlik ve güvenirlik çalışması. The Journal of Academic Social Science Studies, 6(3), 591-600.

Schonert-Reichl, K. A., \& Lawlor, M. S. (2010). The effects of a mindfulness-based education program on pre-and early adolescents' well-being and social and emotional competence. Mindfulness, 1(3), 137-151. http://dx.doi.org/10.1007/s12671-010-0011-8

Seçer, İ. (2015). SPSS ve LISREL ile pratik veri analizi. (2. Baskı) Ankara: Anı Yayıncılık. 
Simões, C., Matos, M., \& Social, E. D. P. A. (2012). Risk behaviors in adolescents with special needs: Are social and emotional competences important?. Procedia-Social and Behavioral Sciences, 69, 2219-2227. http://dx.doi.org/10.1016/j.sbspro.2012.12.191

Sklare, G. B. (2013). Okul danışmanları için çözüm odaklı kısa süreli psikolojik danışma. (4. Baskı). ( Çev. D. M. Siyez ). Ankara: Pegem Akademi Yayıncılık.

Ten Dam, G., \& Volman, M. (2007). Educating for adulthood or for citizenship: Social competence as an educational goal. European Journal of Education, 42(2), 281-298. http://dx.doi.org/10.1111/j.1465-3435.2007.00295.x

Torres, M. V. T., Cardelle-Elawar, M., Mena, M. J. B., \& Sanchez, A. M. M. (2003). Social background, gender and self-reported social competence in 11-and 12-year-old Andalusian children. Electronic Journal of Research in Educational Psychology, 1(2), 38-56.

Usher, L. V., Burrows, C. A., Schwartz, C. B., \& Henderson, H. A. (2015). Social competence with an unfamiliar peer in children and adolescents with high functioning autism: Measurement and individual differences. Research in Autism Spectrum Disorders, 17, 25-39. http://dx.doi.org/10.1016/j.rasd.2015.05.005

Yalçın, D. A. (2009). Sosyal yetkinlik ve davranış değerlendirme ölçeği’nin psikometrik değerlendirmesi, Yüksek Lisans Tezi, Boğaziçi Üniversitesi Sosyal Bilimler Enstitüsü, İstanbul.

Zhang, F., You, Z., Fan, C., Gao, C., Cohen, R., Hsueh, Y., \& Zhou, Z. (2014). Friendship quality, social preference, proximity prestige, and self-perceived social competence: Interactive influences on children's loneliness. Journal of School Psychology, 52(5), 511-526. http://dx.doi.org/10.1016/j.jsp.2014.06.001

\section{$(\mathrm{Cc})$ BY}

This work is licensed under a Creative Commons Attribution 3.0 License. 